Keeping the South Pole clean

Washington

A SERIES of accidents in the Antarctic this year, coming on top of accusations that US research bases are polluting the Antarctic environment, is causing increasing concern over US Antarctic policy. At a Senate hearing last week to assess the progress of the National Science Foundation's (NSF) clean-up operation, the debate widened into general discussion of how to protect the Antarctic environment. Next month, the Senate must decide whether to ratify the Convention on the Regulation of Antarctic Mineral Resource Activities (CRAMRA), which would in principle allow commercial mineral exploration and extraction to begin.

Even with less than a thousand researchers and a few thousand tourists in the area, damaging accidents have occurred. Peter E. Wilkniss, director of Polar Programs at NSF, told the Senate Committee on Commerce, Science and Transportation that the Argentinian vessel wrecked in January off Palmer station (Nature 337, $495 ; 1989)$ still contains 60,000 of diesel oil, which is slowly leaking into the ocean. James N. Barnes of the Antarctica Project said that two other accidents took place in February, involving the Peruvian ship BIC Humboldt and the British resupply vessel HMS Endurance. Although both accidents went largely unreported, either could have caused serious marine pollution.

The diesel spill occurred in a dangerous offshore channel near Palmer station despite warnings from US personnel. According to Barnes, Antarctic navigation is made more difficult by the lack of a single set of accepted charts.

The frequency of accidents and lack of international cooperation increases concern over what might happen if Antarctica is opened up to commercial mineral exploration. At present even prospecting is banned, although seismic surveys have CERN

\section{Finland to join}

\section{London}

FINLAND is to start negotiations with the European Laboratory for High-Energy Physics (CERN) with the aim of becoming the fifteenth member of the organization by 1991, it was announced in Helsinki on 29 August. Finland expects there to be a transition period after full membership during which its membership fee will gradually increase to its full contribution, calculated at almost 2 per cent of the CERN budget on the basis of spending figures for 1989 . CERN welcomes the development, saying that it completes the geographical participation of Western European countries.

Ben Webb been conducted for 'research' purposes. The ban was agreed as a temporary measure while CRAMRA was being negotiated. If ratified by 16 of the 22 member states, CRAMRA would allow mineral exploration and development, although each project would have to be approved by all members and strict environmental standards would be imposed.

Both Australia and France have expressed opposition to the convention, and a number of other Antarctic Treaty member nations are thought to be ambivalent. Australia favours a permanent ban on mineral development, but $\mathrm{R}$. Tucker Scully, director of Marine Science and Polar Affairs at the State Department, said this would be not only undesirable but also politically impossible, because a consensus of nations would be required.

Most independent environmental organizations oppose CRAMRA; Barnes argued that CRAMRA's mere existence would spur commercial competition and accelerate development. But the Ocean Resources Institute takes a different view. Its director, Lee Kimball, feels that "international laws are more durable than political bans" and sees the regulations of the convention as necessary protection in the unwelcome but not unlikely event that mineral prospecting will take place.

Of more immediate concern to both environmental groups and the US government is the mess created by 30 years of research activities. Reports produced last summer by environmental groups (Nature 334, 643; 1988 and 337, 399; 1989) have accused NSF of polluting the unspoilt polar environment, and NSF has admitted that corrective action is needed. One problem is not knowing what has been dumped or released into the environment in the past: Wilkniss says that divers have stumbled upon bulldozers of which there is no record. Some progress has been made in cleaning up old buildings, outdoor storage areas and re-landscaping landfill dumps, but open burning of rubbish continues in contravention of applicable international law and raw sewage is still discharged into the sea. The NSF is requesting $\$ 10$ million in 1990 as the first increment in a $\$ 180$-million, five-year environmental health and safety initiative for it's Antarctic Program.

Environmental issues will be high on the agenda when Antarctic Treaty states meet in Paris next month. Australia has proposed a "comprehensive environmental protection" convention, and the United States has suggested a more permanent infra-structure, in the form of a secretariat that could take responsibility for ensuring compliance with the regulations that exist.

\section{ESA tries to change NASA's mind}

Paris

SENIOR representatives of the European Space Agency (ESA) are this week returning to Washington in a further effort to persuade the US National Aeronautics and Space Administration (NASA) to abandon proposals to cut back on its Freedom space station (see Nature 341, 3; 7 September 1989). The plans, which could involve both an extension of the construction timetable and reductions in engineering specifications for Freedom, are unacceptable to both Japan and ESA and discussions in Washington last week failed to produce a solution.

Dr Frederick Engström, ESA's director of space station and platforms, does not rule out the possibility of changing construction schedules and is optimistic that an "equitable" agreement can be reached "if everybody is willing". But, he says, "the situation is much deeper than this".

The current proposals, which include a halving of available power, would, he says, mean that "there are really no resources available to operate anything but a US lab" and fears that there would be "no technical way to get these resources back within an acceptable time". Rescheduling, he says, would make the Columbus attached laboratory and free flying laboratory "like an appendix" to the main schedule and, from an engineering point of view, "unwelcome".

Among alternative cost-cutting proposals being tabled by ESA are the possibility that, if only one attached laboratory is feasible, this should be built by the partners (ESA and Japan) and not NASA. Also, the US flight tele-robotic servicer could be deferred and its functions performed by the Canadian-built robotic arm until the space station reaches its original specification.

Common mechanisms for decisionmaking exist between ESA and NASA and, says Engström, decisions should be based on consensus. But NASA does have the ability to make decisions unilaterally if no consensus is reached. Memoranda of understanding (MOU) signed between ESA and NASA should have ruled out the possibility of the proposed change in schedule and specifications. "We will have to look at these MOUs", says Engström, "but above all, we have an international governmental agreement which has been signed and ratified. We will have to see whether these agreements have to be adjusted or not."

NASA is expected to reach a decision by the end of this month. Meanwhile, ESA legal experts are looking at the implications of changes in the agreements. The new proposals will be high on the agenda at ESA's science programme committee meeting on 20 September.

Peter Coles 